DE DE GRUYTER OPEN
Journal of Intercultural Management

Vol. 6, No. 3, September 2014, pp. 101-110

DOI 10.2478/joim-2014-0022

Emilia Grzegorzewska*

Warsaw University of Life Sciences, SGGW

\title{
Chosen aspects of economic profitability in agricultural companies in the context of global economic crisis ${ }^{1}$
}

\begin{abstract}
Negative consequences of the economic crisis, which began in the United Sates in 2007, affected economies of all countries. The unfavourable economic situation on world markets was also reflected in the financial condition of Polish companies. It also refers to agriculture which plays a significant role in Polish economy. The following paper covers change trends in economic profitability of a group of 10 agricultural companies. Chosen liquidity and profitability ratios have been presented as well as synthetic measure which is at the root of the compilation "Ranking of 300 best agricultural companies". The presented findings cover the years 2007-2012.
\end{abstract}

Key words: agricultural companies, global crisis, economic profitability, „Ranking 300”

\section{Introduction}

Crisis, which affected markets, institutions and different types of financial assets led, not for the first time in history, to a global crisis. This time, however, due to its range and harsh consequences, it was compared to the Great Crisis from the 1930s [Mitręga, Niestrój 2012, p. 49]. The recent financial crisis risks reversing the region's recent gains and exposes the region to significant adverse economic and social impacts as the economies in Europe and Central Asia are forecast to experience the deepest contraction among all emerging and developing economies [The Impact... 2010, p. 83]. At first the negative consequences of the crisis which began in the United States in 2007 were not severe for Polish economy. However, already in the year 2008 it was emphasized that the economic situation in the world was

\footnotetext{
1 The research has been conducted within the project "Bankruptcy prediction in agricultural companies" (No. N N112 3814 70) financed by National Science Centre.

*emilia_grzegorzewska@sggw.pl
} 
going to be poor for a long time and it could by no means be disregarded (resulting from, inter alia, continuity of changes in the financial sector, possibility of inflationary pressure, considerable halt to globalizing processes and the necessity of solving gigantic problems of public finance) [Global Financial Stability Report GFSR Market Update 2008, p. 10].

The intensity of crisis is different between countries and it has affected mainly the resource rich countries. In general, the crisis affected the economy in the region through reduced capital flows, namely a decline in investments, a decline in domestic production and exports, and a decline in remittances [World Bank, 2009, p. 25]. As it was emphasized by the analysts of the international advisor company Deloitte, in the first quarter of 2013 weakening market environment was still tangible in the euro zone and it is possible that the situation will not change in the next quarters. It means that the "euro zone" has been in recession for more than six quarters, the longest recession in its 14-year history [Global Economic Outlook 2013, p. 6].

Due to the fact that all sectors of economy are inextricably linked, crisis events influenced the condition of agriculture and subjects functioning on this market. In the agricultural sector the most significant symptoms of the recession comprise: fall in demand for produce, lowering the purchase price of milk, decrease in export of farm and food products, decrease in the use of mineral fertilizers, increase in the surplus of workforce, further widening of price scissors, worsening of the situation of food economics, increase of the area of fallow and waste land [Rokicki 2009, p. 1]. The above-mentioned reasons also undoubtedly influence the financial condition of agricultural companies.

\section{Objective and research methodology}

The primary objective of the conducted research was to evaluate economic profitability of the companies ranked as 300 best agricultural companies.

Research material comprised empirical data derived from "Ranking 300" prepared annually by the Institute of Agricultural and Food Economics (IAFE) in cooperation with the Agricultural Property Agency (APA). The evaluation of the companies comprises economic ratios.

In the classification, the key criterion in ordering the researched companies is synthetic measure. It is composed of four partial ratios [Ranking 300... 2012, pp.26-27]:

- Return on sales ratio - the relation of the profit on sales to the sum of sales revenue from products, commodities and materials;

- Value creation index - the relation of the return on equity and the cost of own capital which has been defined as the sum of the return on assets without risk and the financial risk premium. Medium deposit interest rates have been adopted as risk-free assets for the period of two years inclusively in 2012. They 
were at the level of $(4.7 \%)$ per annum and were identical for all companies. As regards the financial risk premium it was the product of the difference between profitability and interests on debt of each company (the relation of paid interests in 2012 to the sum of long- and short-term liabilities at the end of 2012) and the level of own capital debt burden (total liabilities have been divided by the value of own capital in 2012). Index level higher than one proves the increasing value of the company for its owners.

- Added value ratio - the relation of added value to total revenue. As added value there have been summed up the following: net financial result, amortization, agricultural tax and payments charged on costs, ground rent, compulsory charges on financial result, costs of foreign capital and costs of remuneration and benefits.

- Cash generating ratio - the relation of net operating surplus to the sum of net sales revenue, other operating revenue and extraordinary gains. The operating surplus has been defined through the subtraction of expenses covering operating of the company from its earnings. The receipts have been calculated as the sum of sales revenue, other operating costs and extraordinary gains. The expenses have been calculated as the sum of costs of operational activity, other operating costs, extraordinary losses and compulsory charges on financial result.

Table 1. Partial ratios of synthetic measure in "Ranking 300"

\begin{tabular}{|l|l|}
\hline \multicolumn{1}{|c|}{ Type of ratio } & \multicolumn{1}{c|}{ Definition } \\
\hline Return on sales ratio & profit on sales / sales revenue from products, commodities and materials \\
\hline Value creation index & return on equity / return on assets without risk + equity risk premium \\
\hline Added value ratio & $\begin{array}{l}\text { (net financial result }+ \text { amortization }+ \text { agricultural tax }+ \text { payments } \\
\text { charged on costs }+ \text { ground rent }+ \text { compulsory charges on financial result } \\
+ \text { foreign capital costs }+ \text { remuneration costs and benefits) } / \text { total revenue }\end{array}$ \\
\hline Cash generating ratio & $\begin{array}{l}\text { ((sales revenue from products, commodities and materials }+ \text { other operat- } \\
\text { ing revenue }+ \text { extraordinary gains }) \text { (costs of operational activity }+ \text { other } \\
\text { operating costs }+ \text { extraordinary losses }+ \text { compulsory charges on financial } \\
\text { result) }) / \text { (sales revenue from products, commodities and materials }+ \\
\text { other operating revenue }+ \text { extraordinary gains) }\end{array}$ \\
\hline
\end{tabular}

Source: own study on the basis of "Ranking of 300 best agricultural companies in 2012” p. 26-27.

Source data have been collected by the Institute of Agricultural and Food Economics (IAFE) with the use of survey questionnaire sent by post or e-mail. The companies have been classified on the following basis - higher position of the company in each partial ratio translates into its higher final position in the ranking [Ranking 300... 2012, p. 26].

Due to the great number of the researched collectivity, 10 companies have been analyzed in the following article, the ones that in the years 2010-2012 occupied 
leading places in „Ranking 300”. The time frame of the research has been extended to the years 2007-2012. It has been recognized that such a time frame made it possible to observe some change trends regarding the level of chosen profitability ratios of these economic subjects.

\section{Research findings}

\section{Characteristics of the companies}

Ten companies have been chosen for the research. The companies were in the lead of 50 best agricultural companies in the years 2010 - 2012. The analysis comprised those economic subjects that agreed to reveal their names. To keep comparability of the data, another condition required being listed in the Ranking in the researched years that is in the years 2007-2012.

The research has been conducted on the basis of statistical data of 8 companies oriented at crop production and 2 companies that have run additional animal production (the so-called mixed production orientation) (table 2). The analyzed economic subjects are located in six voivodeships: Pomeranian, West Pomeranian, Lublin, Opole, Kuyavian-Pomeranian and Lower Silesian. The companies employed from 2 workers in GR Derczewo to 42 employees in RSP Hopkie. The analyzed group comprised 4 micro-companies as regards the level of employment and 6 small companies. When it comes to the area of agricultural land it made up between 170 ha in GR DERCZEWO and 982 ha in RSP Hopkie. It needs to be noted, however, that in the 2012 Ranking there were only 4 companies that employed more than 249 workers and 41 economic subjects that employed between 50 and 249 workers. It means that $85 \%$ of all companies employed up to 49 workers.

Table 2. Chosen information on the researched companies

\begin{tabular}{|c|c|c|c|c|c|}
\hline & $\begin{array}{l}\text { Name of the com- } \\
\text { pany }\end{array}$ & Voivodeship & $\begin{array}{c}\text { Orientation } \\
\text { of the pro- } \\
\text { duction }\end{array}$ & $\begin{array}{c}\text { Employment } \\
\text { [number of } \\
\text { workers] }\end{array}$ & $\begin{array}{c}\text { The area of } \\
\text { agricultural } \\
\text { land [ha] }\end{array}$ \\
\hline 1 & GR ADKONIS & Pomeranian & Crop & 4 & 485 \\
\hline 2 & GR DERCZEWO & West Pomerania & Crop & 2 & 170 \\
\hline 3 & GR Hulcze & Lublin & Crop & 20 & 874 \\
\hline 4 & AGA-AGRO & Opole & Crop & 6 & 485 \\
\hline 5 & PR-P FARMCO & Lower Silesian & Mixed & 11 & 608 \\
\hline 6 & PRUH BUKOROL & Opole & Crop & 15 & 637 \\
\hline 7 & RSP Maniów Wielki & Lower Silesian & Crop & 8 & 408 \\
\hline 8 & ZPR Kowróz & $\begin{array}{l}\text { Kuyavian -Pomera- } \\
\text { nian }\end{array}$ & Crop & 24 & 994 \\
\hline 9 & PPHU BARYCZ & Lower Silesian & Mixed & 14 & 852 \\
\hline 10 & RSP Hopkie & Lublin & Crop & 42 & 982 \\
\hline
\end{tabular}

Source: own study on the basis of "Ranking of 300 best agricultural companies in 2012" 


\section{Profitability analysis}

Profitability evaluation of the companies began with the analysis of return on sales ratio. As it has been already defined, it denotes the relation of profit on sales to the sales revenue. From the research it follows that the lowest level of the ROS ratio was noted in the years 2008-2009 (table 3). At that time, more than a half of the researched companies made a loss in sales which resulted in the negative ROS ratio. Since 2010 visible improvement in the field has been observed. In the years 2007-2012 the greatest values of the ratio were noted by GR ADKONIS and GR DERCZEWO. In 2012 the ROS ratio was at the level 38.33\% and $46.77 \%$, respectively. It has to be noted that companies produced a positive financial result in sales in the whole analyzed period. Additionally, favourable tendencies in this field were observed in GR Hulcze and PRUH BUKOROL.

In the years 2007-2012 in the researched companies the return on assets ratio (ROA) was positive. It means that the researched group achieved a positive net financial result. It needs to be emphasized that, however, there was a decrease in the return on assets in the years 2008-2009. The companies developed lesser ability to generate profits through the use of their assets. However, the company GR DERCZEWO was an exception - in 2009 it delivered a record great return on assets ratio - 47.21\%. Since next year most of the agricultural companies experienced a significant increase in the relation of net profit to total assets. In the years 2011-2012 the situation stabilized - in that period the level fluctuations of ROA ratios were minor.

Similar tendencies as regards the ROA ratio were apparent in the analysis of return on equity. It needs to be stressed that the researched companies achieved positive financial results even in the crisis years in Poland. It has to be noted, however, that in that period the effectiveness of own capital decreased. Still, in the years 2010-2012 there was a considerable improvement in the use of own capital. In the researched companies the return on equity ratios (ROE) were high - above 15\%.

Table 3. Return on sales, assets and equity in the researched agricultural companies in the years 2007-2012

\begin{tabular}{|c|c|c|c|c|c|c|}
\hline Name of the company & 2007 & 2008 & 2009 & 2010 & 2011 & 2012 \\
\hline \multicolumn{7}{|l|}{ Return on sales ratio $[\%]$} \\
\hline GR ADKONIS & 55.45 & 48.24 & 28.14 & 66.76 & 59.38 & 38.33 \\
\hline GR DERCZEWO & & 36.14 & 23.43 & 35.10 & 43.62 & 46.77 \\
\hline GR Hulcze & 55.49 & 35.78 & 10.59 & 31.86 & 22.48 & 16.66 \\
\hline AGA-AGRO & 37.84 & -9.32 & -25.11 & 31.31 & 28.20 & 20.62 \\
\hline PR-P FARMCO & -2.48 & -9.92 & 3.34 & 5.41 & 26.06 & 19.14 \\
\hline PRUH BUKOROL & 20.15 & 6.28 & 6.60 & 9.34 & 22.06 & 23.41 \\
\hline RSP Maniów Wielki & 23.12 & -44.97 & -11.18 & 7.55 & 6.50 & -7.54 \\
\hline ZPR Kowróz & 6.63 & -0.60 & -12.95 & 24.18 & 16.80 & 26.29 \\
\hline PPHU BARYCZ & -0.80 & -32.67 & -37.24 & 2.41 & 11.13 & -3.12 \\
\hline
\end{tabular}




\begin{tabular}{|c|c|c|c|c|c|c|}
\hline RSP Hopkie & 24.29 & -3.90 & -13.69 & 25.30 & 16.99 & 7.30 \\
\hline \multicolumn{7}{|l|}{ Return on assets ratio [\%] } \\
\hline GR ADKONIS & 19.90 & 31.37 & 12.62 & 55.91 & 36.57 & 21.76 \\
\hline \multirow[t]{2}{*}{ GR DERCZEWO } & & 11.09 & 47.21 & 14.94 & 21.40 & 23.17 \\
\hline & 28.55 & & 11.52 & 21.06 & 17.57 & 18.49 \\
\hline GR Hulcze & & 20.91 & & & & \\
\hline AGA-AGRO & 20.18 & 0.91 & 6.87 & 17.08 & 16.34 & 14.31 \\
\hline PR-P FARMCO & 12.62 & 3.75 & 10.26 & 19.29 & 34.75 & 36.20 \\
\hline & 17.98 & 16.24 & 11.46 & & 13.22 & 15.26 \\
\hline PRUH BUKOROL & & & & 12.08 & & \\
\hline RSP Maniów Wielki & 18.27 & 10.94 & 3.82 & 20.97 & 18.51 & 13.37 \\
\hline ZPR Kowróz & 20.59 & 24.18 & 9.90 & 18.98 & 16.51 & 20.59 \\
\hline PPHU BARYCZ & 22.39 & 5.25 & 11.80 & 24.59 & 22.08 & 15.92 \\
\hline RSP Hopkie & 19.40 & 9.66 & 7.90 & 22.37 & 15.45 & 11.70 \\
\hline \multicolumn{7}{|l|}{ Return on equity ratio [\%] } \\
\hline GR ADKONIS Kwakowo & 20.34 & 33.76 & 13.10 & 58.99 & 44.02 & 25.99 \\
\hline GR DERCZEWO Derczewo & & 12.03 & 53.77 & 26.67 & 50.68 & 46.38 \\
\hline GR Hulcze & 46.37 & 38.28 & 24.55 & 35.67 & 26.75 & 25.22 \\
\hline AGA-AGRO Lukowice Brzeskie & 32.11 & 1.42 & 11.16 & 22.79 & 19.65 & 17.33 \\
\hline PR-P FARMCO Wilczkowice & 16.68 & 6.25 & 14.96 & 26.72 & 41.44 & 40.20 \\
\hline PRUH BUKOROL Bukowice & 24.57 & 21.90 & 15.59 & 15.21 & 18.87 & 20.45 \\
\hline RSP Maniów Wielki & 29.02 & 15.87 & 6.64 & 26.62 & 24.06 & 17.96 \\
\hline ZPR Kowróz & 35.42 & 30.49 & 20.29 & 31.51 & 23.83 & 25.68 \\
\hline PPHU BARYCZ Gądkowice & 25.71 & 6.10 & 13.21 & 26.78 & 25.8 & 18.04 \\
\hline RSP Hopkie & 21.39 & 11.04 & 8.84 & 24.59 & 16.90 & 12.68 \\
\hline
\end{tabular}

Source: own study on the basis of "Ranking of 300 best agricultural companies" in the years 2007-2012.

In the "Ranking 300", next to profitability ratios, evaluation of liquidity is a significant aspect (table 4). The ratio of current liquidity is calculated as a quotient of current assets excluding short-term prepayments and short-term liabilities. In the analysed period the ratio in question was above the limit value which in literature is defined as around 2. In agricultural companies, due to the need of keeping high level of production inventory and commodity products, the optimal level of the current liquidity ratio is higher than presupposed in literature, that is around 3 , when assumed, that it is calculated on the basis of current assets and current liabilities at the end of the calendar year, that is with high level of inventory [Runowski 2008, p. 161]. Thus, taking into account the optimal level of current liquidity ratio for agricultural companies, the companies that did not manage to settle short-term liabilities were the following: AGA-AGRO in the years 2007-2009, and ZPR Kowróz excluding the years 2008 and 2012. Significant attention needs to be 
paid to the company RSP Hopkie that in the analysed period achieved considerable overliquidity. A similar situation was noted in PR-P FARMCO Wilczkowice (in the years 2011-2012) and PRUH BUKOROL (in the years 2009-2012). It needs to be noted, however, that too high level of the current liquidity ratio is not a favourable situation. It may result from upholding high levels of the mentioned assets which more often than not manifests non-effective assets management.

Similar tendencies were noted as regards the quick ratio which the relation of current assets excluding inventory and short-term prepayments to short-term liabilities. In agricultural companies the ratio is supposed to be around 1.4 [Runowski 2008, p. 161]. As a rule, the researched companies were capable of settling current liabilities with the use of current assets excluding the inventory. It ought to be emphasized that the value of the quick ratio far too below the limit value was noted in AGA-AGRO. It was typical of the whole period excluding the year 2011. On the other hand, significant overliquidity in the field was noted in, inter alia, RSP Hopkie, PRUH BUKOROL and PR-P FARMCO.

In "Ranking 300" the evaluation of financial liquidity was conducted on the basis of the company ability to cover liabilities with the use of financial surplus (credit capacity ratio). It is defined as a relation between the sum of net financial result and amortization to the value of total liabilities. The ratio denotes what part of total liabilities the company settles with the worked out financial surplus. The higher value of the ratio in question, the shorter time needed for the company to pay off its liabilities.

In the years 2008-2009 the researched agricultural companies developed the lowest ability to cover liabilities with the use of the earned financial surplus. Since 2010 a rise in the value of the ratio in most of the companies has been noted. It manifests itself in shortening the time necessary for paying off liabilities with the use of financial surplus.

Table 4. Liquidity ratios in the researched companies in the years 2007-2012

\begin{tabular}{|l|l|l|l|l|l|l|}
\hline Name of the company & \multicolumn{1}{|c|}{$\mathbf{2 0 0 7}$} & \multicolumn{1}{|c|}{$\mathbf{2 0 0 8}$} & \multicolumn{1}{|c|}{$\mathbf{2 0 0 9}$} & \multicolumn{1}{|c|}{$\mathbf{2 0 1 0}$} & \multicolumn{1}{|c|}{$\mathbf{2 0 1 1}$} & $\mathbf{2 0 1 2}$ \\
\hline Current liquidity ratio \\
\hline GR ADKONIS & 36.84 & 9.78 & 19.38 & 7.67 & 3.14 & 3.5 \\
\hline GR DERCZEWO & 0.18 & no data & no data & no data & no data & no data \\
\hline GR Hulcze & 8.00 & 14.52 & 5.55 & 3.87 & 8.8 & 7.6 \\
\hline AGA-AGRO & 2.24 & 1.56 & 1.01 & 3.00 & 5.58 & 2.8 \\
\hline PR-P FARMCO & 3.71 & 3.03 & 4.04 & 8.54 & 40.02 & 43.8 \\
\hline PRUH BUKOROL & 7.77 & 7.59 & 17.22 & 28.75 & 29.9 & 27.5 \\
\hline RSP Maniów Wielki & 28.04 & 2.37 & 2.67 & 4.81 & 5.86 & 3.7 \\
\hline ZPR Kowróz & 2.35 & 9.36 & 4.58 & 3.77 & 2.72 & 12.7 \\
\hline PPHU BARYCZ & 4.68 & 4.03 & 4.63 & 7.42 & 5.04 & 6.7 \\
\hline RSP Hopkie & 47.69 & 43.47 & 29.71 & 46.33 & 40.27 & 32.3 \\
\hline
\end{tabular}




\begin{tabular}{|l|l|l|l|l|l|l|}
\hline Quick ratio \\
\hline GR ADKONIS & 36.56 & 9.78 & 18.75 & 7.67 & 3.14 & 3.5 \\
\hline GR DERCZEWO & 0.08 & no data & no data & no data & no data & no data \\
\hline GR Hulcze & 4.08 & 9.80 & 2.55 & 2.32 & 4.42 & 4.60 \\
\hline AGA-AGRO & 0.28 & 0.21 & 0.09 & 0.63 & 1.58 & 0.6 \\
\hline PR-P FARMCO & 0.94 & 0.72 & 1.13 & 2.21 & 11.43 & 24.6 \\
\hline PRUH BUKOROL & 3.86 & 4.20 & 9.23 & 14.5 & 15.72 & 16.3 \\
\hline RSP Maniów Wielki & 15.04 & 1.23 & 2.03 & 1.74 & 3.99 & 2.4 \\
\hline ZPR Kowróz & 0.95 & 3.93 & 2.85 & 1.42 & 1.73 & 8.4 \\
\hline PPHU BARYCZ & 2.70 & 1.56 & 2.17 & 4.83 & 3.48 & 5.2 \\
\hline RSP Hopkie & 36.10 & 32.62 & 22.48 & 38.25 & 30.4 & 25.9 \\
\hline Credit capacity ratio & \multicolumn{7}{|l|}{} & \multicolumn{1}{l|}{} \\
\hline GR ADKONIS & 9.18 & 4.53 & 3.90 & 11.45 & 2.37 & 1.6 \\
\hline GR DERCZEWO & no data & 1.55 & 4.29 & 0.39 & 0.42 & 0.5 \\
\hline GR Hulcze & 0.87 & 0.54 & 0.31 & 0.62 & 0.64 & 0.9 \\
\hline AGA-AGRO & 0.61 & 0.10 & 0.26 & 0.79 & 1.14 & 1.0 \\
\hline PR-P FARMCO & 0.71 & 0.17 & 0.46 & 0.85 & 2.44 & 4.0 \\
\hline PRUH BUKOROL & 0.88 & 0.86 & 0.69 & 0.76 & 0.53 & 0.7 \\
\hline RSP Maniów Wielki & 1.20 & 1.04 & 0.34 & 2.96 & 3.73 & 1.5 \\
\hline ZPR Kowróz & 0.80 & 2.10 & 0.28 & 0.59 & 0.69 & 1.3 \\
\hline PPHU BARYCZ & 2.10 & 0.98 & 1.88 & 3.83 & 1.91 & 1.8 \\
\hline RSP Hopkie & 3.43 & 1.22 & 1.26 & 3.68 & 2.68 & 2.5 \\
\hline
\end{tabular}

Source: own study on the basis of "Ranking of 300 best agricultural companies" in the years 2007-2012.

Synthesis of the research into economic profitability is the position of the particular companies in the presented Ranking (table 5). In the analysed period the classification of the researched subjects has changed greatly. GR ADKONIS deserves significant attention. At the beginning of the analysed period the company occupied $134^{\text {th }}$ place in the Ranking, and in the years 2010-2011 came first in the classification. Another company that enjoyed significant improvement in the field was GR DERCZEWO. In 2007 the company was $208^{\text {th }}$, however, since 2009 it has been in the first five of the Ranking. The opposite situation was noted in RSP Maniów Wielki (fall from the $10^{\text {th }}$ place to the $82^{\text {nd }}$ ) and RSP Hopkie (fall from position 48 to 66).

Table 5. Position of the researched companies in the „Ranking 300” in the years 2007-2012

\begin{tabular}{|l|l|l|l|l|l|l|}
\hline \multicolumn{1}{|c|}{ Name of the company } & \multicolumn{1}{c|}{$\mathbf{2 0 0 7}$} & \multicolumn{1}{c|}{$\mathbf{2 0 0 8}$} & $\mathbf{2 0 0 9}$ & $\mathbf{2 0 1 0}$ & $\mathbf{2 0 1 1}$ & \multicolumn{1}{c|}{$\mathbf{2 0 1 2}$} \\
\hline GR ADKONIS & 134 & 4 & 7 & 1 & 1 & 9 \\
\hline GR DERCZEWO & 298 & 204 & 3 & 4 & 3 & 2 \\
\hline GR Hulcze & 5 & 2 & 10 & 2 & 6 & 48 \\
\hline AGA-AGRO & 13 & 252 & 50 & 7 & 8 & 30 \\
\hline
\end{tabular}




\begin{tabular}{|l|l|l|l|l|l|l|}
\hline PR-P FARMCO & 181 & 163 & 88 & 38 & 4 & 8 \\
\hline PRUH BUKOROL & 39 & 8 & 12 & 27 & 10 & 23 \\
\hline RSP Maniów Wielki & 10 & 25 & 98 & 10 & 20 & 82 \\
\hline ZPR Kowróz & 108 & 41 & 60 & 12 & 58 & 36 \\
\hline PPHU BARYCZ & 102 & 190 & 102 & 16 & 18 & 80 \\
\hline RSP Hopkie & 48 & 66 & 58 & 11 & 47 & 66 \\
\hline
\end{tabular}

Source: own study on the basis of "Ranking of 300 best agricultural companies" in the years 2007-2012.

\section{Summary}

Global economic crisis influenced, to a lesser or greater degree, economic situation of all countries and most sectors of the economy. As a result of crisis events, the situation of the economic subjects listed in the Ranking of 300 best agricultural companies compiled annually by IAFE changed.

The lowest level of return on sales ratio was noted in the researched group in the years 2008-2009. In that period almost half of the companies made a loss in sales. Similar downward trends were noted as regards the ROA ratio which proved lesser ability to generate profits through the companies' own assets. It needs to be stressed, however, that the researched companies achieved a positive net financial result, which resulted in positive values of the ROA ratio. In the years 2008-2009 the financial effectiveness of own capital decreased as well.

It also has to be emphasised that respective positions of given companies were changing in the Ranking as a result of achieving different values of the rations that make up synthetic measure used in the classification of these economic subjects.

\section{Bibliography}

Fan, S., Rosegrant M. W. (2008) Investing in Agriculture to Overcome the World Food Crisis and Reduce Poverty and Hunger, International Food Policy Research Institute, Policy Brief 3

Global Financial Stability Report - GFSR Market Update 2008, p. 10

Mitręga-Niestrój, K. (2012) Problem zarażania kryzysem finansowym oraz kanały jego transmisji do strefy realnej $w$ aspekcie globalnego kryzysu finansowego i gospodarczego - studium teoretycznoempiryczne, Oddzialywanie globalnego kryzysu finansowego. Perspektywa przedsiebiorstwa, J. Błach, M. Gorczyńska i in., Wydawnictwo CeDeWu, Warszawa 2012, p. 49.

"Ranking of 300 best agricultural companies in 2007" "Ranking of 300 best agricultural companies in 2008 " "Ranking of 300 best agricultural companies in 2009" "Ranking of 300 best agricultural companies in 2010"

"Ranking of 300 best agricultural companies in 2011"

"Ranking of 300 best agricultural companies in 2012" 
Rokicki T. (2009) Wplyw kryzysu gospodarczego na rynki produktów rolnych; http://www.konferencja.edu.pl/, p. 1.

Runowski, H. (2008) Tendencje zmian w ekonomice przedsiębiorstw hodowlanych w latach 1997 2007, Roczniki Nauk Rolniczych. Seria G - Ekonomika Rolnictwa, nr 1, p. 161.

The Impact of the Economic and Financial Crises on Agriculture and Food Security in Europe and Central Asia: a Compendium, Food and Agriculture Organization Regional Office for Europe and Central Asia, Budapest 2010, p. 83.

World Bank (2009) Turmoil at Twenty - Recession, Recovery, and Reform in Central and Eastern Europe and the Former Soviet Union, World Bank, Washington D.C., p. 25. 